\title{
Frequency of Injuries from Line Entanglements, Killer Whales, and Ship Strikes on Bering-Chukchi-Beaufort Seas Bowhead Whales
}

\author{
J. Craig George, ${ }^{1,2}$ Gay Sheffield, ${ }^{3}$ Daniel J. Reed, ${ }^{4}$ Barbara Tudor, ${ }^{1}$ Raphaela Stimmelmayr,${ }^{1,5}$ \\ Brian T. Person, ${ }^{1}$ Todd Sformo ${ }^{1,5}$ and Robert Suydam ${ }^{1}$
}

(Received 9 May 2016; accepted in revised form 18 October 2016)

\begin{abstract}
We analyzed scarring data for Bering-Chukchi-Beaufort (BCB) Seas bowhead whales (Balaena mysticetus) harvested by Alaska Native hunters to quantify the frequency of line entanglement, ship strikes, and killer whale-inflicted injuries. We had 904 records in our database for whales landed between 1990 and 2012, and after data quality screening, we found 521 records containing information on scarring. Logistic regression was used to evaluate different combinations of explanatory variables (i.e., body length, sex, year, year-group) to develop a prediction model for each scar type. We also list bowhead whales that were harvested, found dead, or observed alive entangled in commercial line/fishing gear. Our findings suggest that about $12 \%$ of harvested bowheads show entanglement scars. Their frequency is highly correlated with body length and sex: about $50 \%$ of very large bowheads $(>17 \mathrm{~m}$ ) show such scars, while whales under $9 \mathrm{~m}$ rarely do, and males show a significantly higher rate than females. Scars associated with ship strikes are infrequent and occur on $\sim 2 \%$ of all harvested whales; body length, sex, and year were not significant factors. Scarring from attempted killer whale predation was evident on $\sim 8 \%$ of landed whales. As with entanglement injuries, the frequency of killer whale scars was much higher $(>40 \%)$ on whales more than $16 \mathrm{~m}$ in length and statistically more frequent in the second half of the study $(2002-12)$. Increased killer whale injuries in the recent decade are consistent with studies conducted on bowheads of the Eastern Canada-West Greenland population. The findings presented here reflect the most thorough analysis of injury rates from entanglement, ships, and killer whales for the BCB bowheads conducted to date. They indicate that (1) entanglement rates primarily from pot fishing gear (crab or cod or both) are relatively high for very large and presumably older bowheads, (2) collisions with ships are infrequent at present, and (3) scarring from killer whales is frequent on very large adult whales (>17 m). Considering that bowhead habitat is changing rapidly (e.g., sea ice reduction), industrial ship traffic in the Arctic is increasing, and commercial fishing operations are expanding to the north, we strongly recommend that monitoring of scarring and injuries on harvested bowheads continue into the future as a means of documenting change.
\end{abstract}

Key words: bowhead whale; Balaena mysticetus; ship strike; Arctic Ocean; Bering Sea; line entanglement; commercial gear entanglement; Orcinus orca; killer whale predation attempts; propeller injuries; scars; aboriginal whaling

RÉSUMÉ. Nous avons analysé les données sur les cicatrices que portent les baleines boréales (Balaena mysticetus) des mers de Béring, des Tchouktches et de Beaufort capturées par des chasseurs autochtones de l'Alaska afin de quantifier la fréquence d'emmêlements dans des filets de pêche, de collisions avec des navires et de blessures infligées par des épaulards. Notre base de données contenait 904 enregistrements portant sur des baleines prises entre 1990 et 2012 et, après une sélection des données selon leur qualité, nous avons trouvé 521 enregistrements comptant de l'information sur des cicatrices. Une méthode de régression logistique a été utilisée pour évaluer différentes combinaisons de variables explicatives (longueur corporelle, sexe, année et année-groupe, par exemple) afin de concevoir un modèle prédictif pour chaque type de cicatrice. Nous énumérons également les baleines boréales retrouvées emmêlées dans des engins ou des filets de pêche commerciale qui ont été capturées, trouvées mortes ou observées vivantes. Nos découvertes suggèrent qu'environ $12 \%$ des baleines boréales capturées portent des cicatrices causées par l'emmêlement. La fréquence des cicatrices est étroitement liée à la longueur corporelle et au sexe : environ $50 \%$ des baleines boréales de très grande taille $(>17 \mathrm{~m})$ montrent de telles cicatrices, tandis que les baleines mesurant moins de $9 \mathrm{~m}$ portent rarement de telles cicatrices. Par ailleurs, les mâles affichent beaucoup plus de cicatrices que les femelles. Les cicatrices reliées à des collisions avec des navires sont rares et n'apparaissent que sur environ $2 \%$ de toutes les baleines capturées; la longueur corporelle, le sexe et l'année n'étaient pas des facteurs importants. Les cicatrices causées par des tentatives de prédation par les épaulards étaient apparentes sur environ $8 \%$ des baleines prises. Comme pour les blessures causées par l'emmêlement, la fréquence des cicatrices causées par des épaulards était beaucoup plus élevée (> $40 \%$ ) sur les baleines mesurant plus de $16 \mathrm{~m}$ de longueur et statistiquement plus fréquente dans la deuxième partie de l'étude

\footnotetext{
${ }^{1}$ North Slope Borough Department of Wildlife Management, PO Box 69, Barrow, Alaska 99723, USA

${ }^{2}$ Corresponding author: craig.george@north-slope.org

${ }^{3}$ University of Alaska Fairbanks, Alaska Sea Grant-Marine Advisory Program, PO Box 400, Nome, Alaska 99762, USA

${ }^{4}$ Alaska Department of Fish and Game, PO Box 1148, Nome, Alaska 99762-1148, USA

${ }^{5}$ Institute of Arctic Biology, University of Alaska Fairbanks, PO Box 757000, Fairbanks, Alaska 99775-7000, USA

(C) The Arctic Institute of North America
} 
(2002 - 12). L'augmentation des blessures causées par des épaulards au cours de la dernière décennie concorde avec les études réalisées sur la population des baleines boréales de l'est du Canada et de l'ouest du Groenland. Les résultats présentés dans cette étude reflètent l'analyse la plus profonde du taux de blessures causées par l'emmêlement, les navires et les épaulards sur les baleines boréales des mers de Béring, des Tchouktches et de Beaufort à avoir été réalisée jusqu'à présent. Les observations indiquent que : 1) le taux d'emmêlement découlant principalement des engins ou casiers de pêche (crabe ou morue ou les deux) est relativement élevé chez les baleines boréales de très grande taille et probablement plus vieilles, 2) les collisions avec les navires sont rares en ce moment, et 3) les cicatrices causées par des épaulards sont fréquentes chez les baleines adultes de très grande taille $(>17 \mathrm{~m}$ ). Étant donné le changement rapide de l'habitat de la baleine boréale (diminution des glaces marines, par exemple), l'augmentation de la circulation maritime industrielle dans l'Arctique et l'intensification des opérations de pêche commerciale au nord, nous recommandons fortement de continuer de surveiller les cicatrices et les blessures des baleines boréales capturées afin de documenter les changements.

Mots clés : baleine boréale; Balaena mysticetus; collision avec des navires; océan Arctique; mer de Béring; emmêlement dans les filets; emmêlement dans les engins de pêche commerciale; Orcinus orca; tentatives de prédation par les épaulards; blessures infligées par des hélices; cicatrices; chasse à la baleine chez les Autochtones

Traduit pour la revue Arctic par Nicole Giguère.

\section{INTRODUCTION}

The bowhead whale (Balaena mysticetus) is a large, slowswimming baleen whale that spends its entire life associated with high-latitude seas. As a general pattern, whales of the Bering-Chukchi-Beaufort (BCB) Seas bowhead population migrate in spring more than $3000 \mathrm{~km}$ from their central and northern Bering Sea wintering grounds to their eastern Beaufort Sea summering area. The return fall migration occurs as the whales travel westward into the Chukchi Sea, along the northeast coast of the Chukotka peninsula, through the Bering Strait, and finally into the northern Bering Sea (Moore and Reeves, 1993; Quakenbush et al., 2010). Their range includes the transboundary waters of the United States (Bering, Chukchi, and Beaufort Seas), the Russian Federation (Bering and Chukchi Seas), and Canada (Beaufort Sea) (Fig. 1).

Studies of scar patterns on whales provide evidence of injuries. Once damaged, the black epidermis of a bowhead whale heals with a white coloration, leaving what appears to be a permanent record of a past physical injury (Philo et al., 1992; Rugh et al., 1992; George et al., 1994; Reinhardt et al., 2013). Data on the scarring of bowhead whales from line entanglements, ship strikes, and killer whales (Orcinus orca) were collected from legally harvested bowheads and also from aerial surveys, opportunistic sightings, and stranding events (Philo et al., 1992, 1993; Reeves et al., 2012; Vate Brattstrom et al., 2016). Close examination of landed whales during spring and fall hunts allows for the collection of invaluable "health-assessment" data from organismal to tissue level and allows close-up examinations of scars that are often not as apparent in aerial photos (e.g., Philo et al., 1993).

Tracking industrial anthropogenic impacts on the $\mathrm{BCB}$ bowhead whale population is important for a number of reasons. Bowheads are (1) essential to the nutritional, cultural, and economic well-being of coastal communities throughout northern and western Alaska and (2) listed as endangered under the Endangered Species Act (ESA).

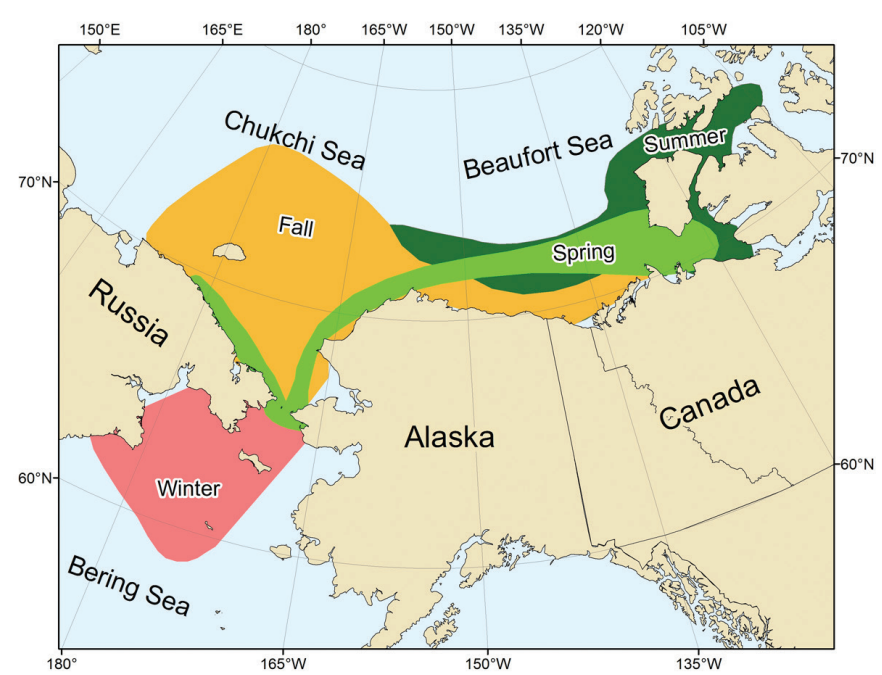

FIG. 1. General range map by season of the Bering-Chukchi-Beaufort Sea bowhead whales based on satellite telemetry data. Note that scattered sightings of bowheads have occurred slightly beyond the depicted boundaries (Quakenbush et al., 2012).

However, at their current population size of about 16800 whales (95\% CI: 15100 to 18700 ; Givens et al., 2016) they are near a full recovery (Brandon and Wade, 2006) and therefore may be considered for ESA "downlisting."

Working collaboratively with Alaska Native bowhead whaling communities along the Beaufort, Chukchi, and Bering Seas, biologists have conducted postmortem examinations on more than 1000 bowhead whales harvested for subsistence since the mid-1970s. For the majority of these field examinations, particularly since 1990, biologists and hunters recorded scarring and categorized scar types.

A similar study was conducted about 25 years earlier to quantify scars attributed to killer whales and ship strikes on harvested bowheads for the period 1976-92 (George et al., 1994). During those years, the field examination forms were not standardized for recording injuries and scar types, which led to some uncertainty about which animals had 
been examined. The authors noted, "One of the greatest difficulties of the analysis was to determine which whales were properly examined for scarring" (George et al., 1994:251). Nonetheless, that work serves as a historical baseline for the current study.

Reduction of Arctic sea ice is leading to increased industrial ship traffic, including but not limited to shipping, offshore resource extraction, commercial fisheries, and tourism (Reeves et al., 2012). An extended duration of the ice-free open water season in northern waters is currently occurring throughout the range of the $\mathrm{BCB}$ bowhead whale population, increasing the likelihood of additional industrial maritime ship traffic, as well as ecosystem-wide changes (Reeves et al., 2012).

Entanglement in commercial fishing gear is one of the leading sources of anthropogenic mortality for whales worldwide and a serious conservation and humane issue. Read et al. (2006) estimated the global bycatch of cetaceans at 307753 animals annually-an alarming figure. In their exhaustive 29-year study, Knowlton et al. (2012) analyzed hundreds of photographs for scarring in the critically endangered North Atlantic right whale (NARW) population, which numbers about 400 animals. They found that $82.9 \%$ had been entangled at least once, and $59.0 \%$ had been entangled "more than once." Entanglement is considered one of the leading causes of mortality and the extremely slow recovery of this population (Knowlton et al., 2012; Moore, 2014).

BCB bowheads bear both direct and indirect evidence of commercial fishing gear entanglement despite their remote distribution in northern and western Alaska away from most commercial operations (Moore et al., 2004; Read et al., 2006; Reeves et al., 2012; Citta et al., 2013). Reeves et al. (2012) reported preliminary findings from postmortem examinations of $459 \mathrm{BCB}$ bowheads landed as part of the subsistence hunts at Barrow and Kaktovik, Alaska, over the period 1988 through 2007. At these two villages, biologists examined about $90 \%$ of the landed whales for scarring and other biological parameters. Preliminary analyses indicated that about $10 \%$ of the whales bore scarring consistent with line-inflicted wounds, and $2 \%-3 \%$ had scars consistent with ship or propeller injuries. At least two landed whales and five dead-stranded whales had pot-fishing gear attached (Reeves et al., 2012).

Regarding killer whale predation, George et al. (1994:253) stated: "The relatively low frequency of bite marks on BCB bowheads likely reflects a relatively low frequency of killer whale attacks..." Reports by hunters of killer whale attacks on BCB bowheads are rare as well (George and Suydam, 1998). However, Saint Lawrence Island hunters have reported successful attacks. In fall 2015, Barrow whaling crews recovered a small whale that did not have hunting gear associated with it, but had evidence (tooth marks) that it was killed by killer whales (DeMarban, 2015; Suydam et al., 2016). The strong recovery of $\mathrm{BCB}$ bowheads suggests that mortality from killer whale predation has historically been low for this population (Givens et al., 2016).

The goal of this study was to compile data and quantify the frequency of scars attributed to line entanglement, ship strike, and killer whale injuries to bowhead whales to better understand the basis and etiology of these injuries. We documented the status of scarring from three sources (i.e., ship strikes, line entanglements, and killer whales) on bowhead whales harvested during subsistence hunts during 1990-2012.

Our specific objectives were (1) to compile data on documented injuries to bowhead whales during 1990-2012, (2) to calculate quantitative estimates of line entanglement, killer whale, and ship strike injuries as a function of body length, sex, year, and year-group, and (3) to provide a comprehensive list of anthropogenic materials recovered from harvested or dead-stranded bowhead whale carcasses and records of live whales carrying gear, during 1983-2015.

\section{METHODS}

We examined records in the North Slope Borough (NSB) database for 904 bowhead whales harvested between 1990 and 2012. Of these, 514 whales were examined for at least one of the three types of scars indicating injuries from line entanglement wounds, attacks by killer whales, and ship strikes (propeller injuries). Characteristics of the harvested whales were included in the analysis model. The explanatory variables were whale length, sex, year, and year-group (1990-2001 vs. 2002-12). Scars of a specific type were scored in the field as "yes," "no," or "possible." The scars were verified by each of the authors familiar with examining and documenting injuries on bowhead whales.

The basic criteria for assigning a scar type were the following:

1. Line entanglement scars are usually about $0.5 \mathrm{~m}$ linear or curvilinear cuts or scars into the skin around the mouth, flippers, flukes, or peduncle region (Fig. 2). These injuries are consistent with the kind of damage a hightension line would make wrapped around the whale's body (Moore et al., 2004).

2. Killer whale wounds are typically short $(\sim 30 \mathrm{~cm})$ parallel linear scars or "rake marks" approximately $2-4 \mathrm{~cm}$ apart on the posterior edge of the flukes, fluke tips, or flippers (Fig. 3).

3. Ship strike injuries are lacerations or incising wounds associated with contact with the spinning propeller of a boat or ship hull (Fig. 4). Typically ship propeller wounds are recognized as a series of parallel concave scars or cuts.

We excluded whales with scars scored as "possible" because we could not assign a probability of these uncertain cases without making unsupported assumptions about them. Thus, in this analysis, the response variables 


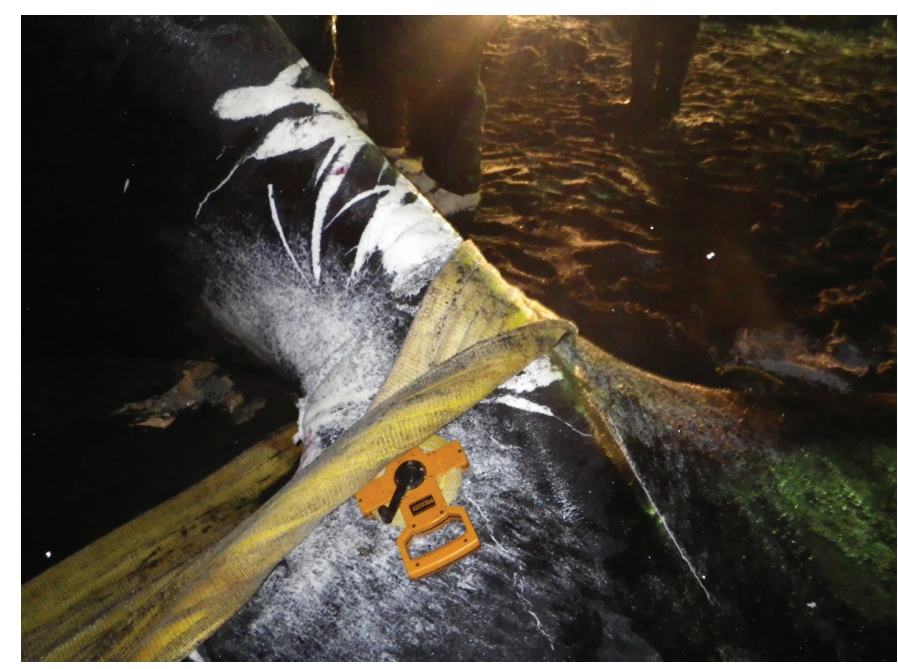

FIG. 2. Line entanglement injury scarring on the dorsal peduncle of an adult female bowhead whale in 2008 (whale 12S8). Photo credit: G. Sheffield.

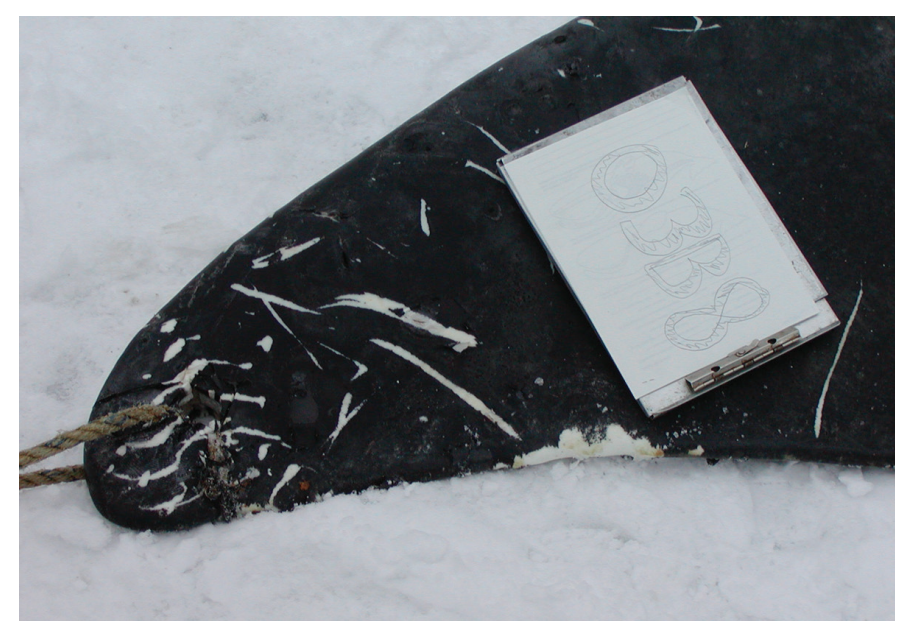

FIG. 3. Killer whale injuries or "rake mark scars" on the fluke tip of a whale landed at Barrow in 2003 (whale 03B8). Photo credit: J.C. George.

were "yes" or "no" for each of the three scar types. We used logistic regression with different combinations of explanatory variables to develop a prediction model for each response variable (Hosmer and Lemeshow, 2000), using the "glm" function from the "stats" library in R (Crawley, 2007; R Development Core Team, 2009).

The specific forms of the logistic function can be written:

$$
\pi(X)=\frac{e^{f(X)}}{1+e^{f(X)}}
$$

where $X$ is a vector of explanatory variables $x_{i}$ of dimension $n\left(X=\left[x_{1}, x_{2}, x_{3}, \ldots x_{n}\right]\right)$ and $\pi(X)$ is the probability that a whale exhibited a certain type of scar, given the values of $X$ for that whale. The logit transformation is defined in terms of $\pi(X)$ as:

$$
f(X)=\ln \left(\frac{\pi(X)}{1-\pi(X)}\right)=\beta_{0}+\beta_{1} x_{1}+\ldots+\beta_{n} x_{n} .
$$

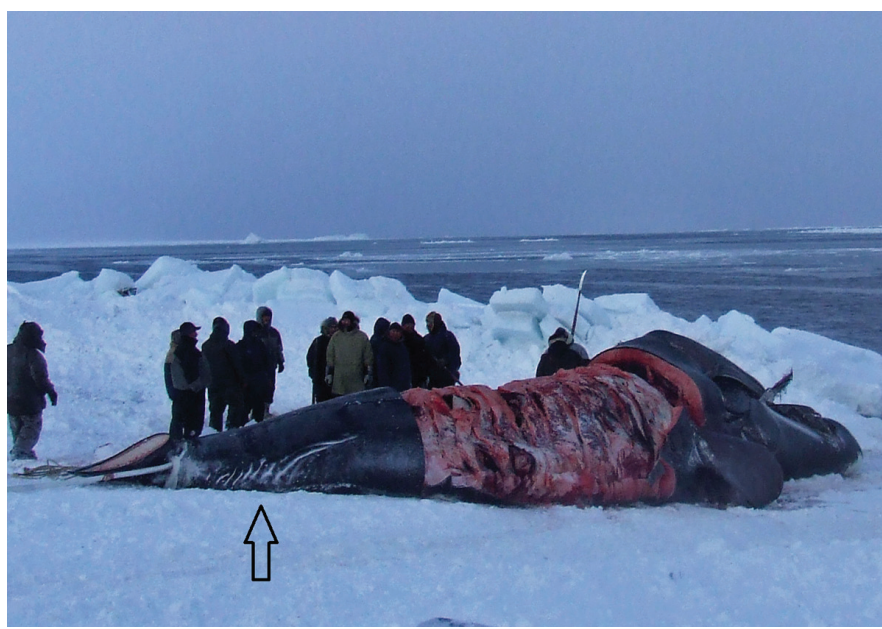

FIG. 4. Ship strike propeller injury scarring on the dorso-lateral region of a bowhead whale legally harvested near Saint Lawrence Island in 2010 (whale 10G2). Photo credit: Samarys Seguinot-Medina.

Only individual and additive combinations of the four explanatory variables were considered-no second- or third-order combinations of explanatory variables were used.

We used Akaike's Information Criterion (AIC) to rank competing models to determine the "best model"- that is, the combination of the four variables (length, sex, year, and year-group) that best explained the data-for each scar type. This criterion evaluates the strength of evidence for each model in a list of a priori identified models. Conditional on the data, $X$, AIC is calculated using the likelihood of each model (i.e., $L\left(f_{j} \mid X\right)$ for model $f_{j}, j=1$ to $R$ ). Specifically:

$$
A I C_{j}=2 K-2 \ln \left(L\left(\hat{\boldsymbol{\beta}}_{j} \mid X\right)\right) \text {. }
$$

where:

$$
L\left(\hat{\boldsymbol{\beta}}_{j} \mid X\right)
$$

is the value of the maximized log-likelihood over the unknown parameters

$$
\left(\hat{\boldsymbol{\beta}}_{j}=\left\lfloor\hat{\beta}_{0}, \hat{\beta}_{1} \ldots \hat{\beta}_{n}\right\rfloor\right)
$$

for model $f$, and $K$ is the number of parameters in that model. The model for which AIC is minimal is selected as the best for the data at hand (Burnham and Anderson, 2002).

Akaike weights $\left(w_{j}\right)$ were calculated to provide a "weight of evidence" in favor of each model being considered as the actual "best model" in the set given $X$. The $w_{j}$ are sometimes interpreted approximately as the probability that model $j$ is the "best" model for the data (Burnham and Anderson, 2001).

Finally, summary statistics were calculated for each scar type. For readers wishing to interpret these results within a hypothesis-testing framework, we have provided the $p$-values for explanatory variables included in the models with the smallest AIC value for each scar type. 
TABLE 1. AIC values used for model selection in identifying explanatory variables for the occurrence of line wound scars, killer whale scars, and ship strike scars on bowhead whales. The AIC model selections evaluated four variables: length, sex, year, and year-group, to determine which best explained the data for each scar type. Models with lower AIC scores are considered better, although AIC differences less than 2 are hardly distinguishable. Akaike weights essentially provide a "weight of evidence" in favor of each model considered as being the actual best model in the set, given the data (higher numbers identify the best model choice).

\begin{tabular}{lrlr}
\hline \hline Scar type & AIC & Explanatory variables & $\begin{array}{r}\text { Akaike } \\
\text { weight }\end{array}$ \\
\hline Line wound & 297.45 & length, sex & 0.896 \\
& 301.75 & length & 0.104 \\
& 359.69 & sex & $<0.001$ \\
& 361.35 & none (estimates a single overall mean) & $<0.001$ \\
& 363.13 & year & $<0.001$ \\
& 363.29 & year-group (1990-2001 vs 2002-12) & $<0.001$ \\
Killer whale & 136.55 & length, year & 0.487 \\
& 136.96 & length, year-group (1990-2001 vs 2002-12) & 0.397 \\
& 139.42 & length & 0.116 \\
& 204.28 & year-group (1990-2001 vs 2002-12) & $<0.001$ \\
& 206.55 & year & $<0.001$ \\
& 209.90 & none (estimates a single overall mean) & $<0.001$ \\
& 211.87 & sex & $<0.001$ \\
& & & \\
Ship strike & 98.87 & length & 0.424 \\
& 99.84 & none (estimates a single overall mean) & 0.261 \\
101.46 & year & 0.116 \\
101.73 & year-group (1990-2001 vs 2002-2012) & 0.101 \\
& 101.82 & sex & 0.097 \\
\hline \hline
\end{tabular}

Observations about "active" line entanglements were derived from aerial photographic surveys conducted by the NSB and NOAA (Vate Brattstrom et al., 2016) and observations reported by hunters from boats.

\section{RESULTS}

Of the 904 bowhead records we examined, 521 included information on scarring, while 514 had all the information required for this analysis (length, sex, and year). Model selection results are shown in Table 1. Table 2 lists the total cases for each scar type.

\section{Line Entanglement}

A total of 514 whales were scored for line entanglement scars. Of these, 59 were determined to have scar patterns consistent with definite line entanglement injuries and 29 had "possible" entanglement scars (Fig. 2). We excluded "possible" entanglement scars, for the reasons explained in the methods, which further reduced the sample to 485 cases available for analysis (Table 2).

The majority of the entanglement injuries occurred to the peduncle (Fig. 2). Body length and sex explained most of the variation in the occurrence of line entanglement scars: longer whales were scarred more frequently than shorter ones $(p<0.001)$, and males were scarred more frequently than females $(p=0.014)$ (Table 1, Fig. 5). Commercial pot gear was removed from an entangled dead adult female found in Kotzebue Sound (Chukchi Sea) in 2010 (Fig. 6; Sheffield, 2010), and Saint Lawrence Island hunters recovered commercial crab pot gear with an identification tag from a dead adult female whale in 2015 (Table 3; Sheffield and Savoonga Whaling Captains Association, 2015).

Entanglement scars were rare on smaller subadult and juvenile whales $(<10 \mathrm{~m})$. Large bowheads had a higher frequency of entanglement scars than smaller age classes (Table 1). For instance, at a body length of $17 \mathrm{~m}$, about $50 \%$ of landed bowhead whales (both sexes) exhibited entanglement scars, with males showing higher rates of scarring (Fig. 5). While the scarring rate is a function of sex and age in this population, we suggest an estimate of $\sim 12.2 \%$ (59/485) for comparison with other whale stocks.

\section{Ship Strikes}

A total of 504 whales were scored for ship strikes, of which only 10 whales ( $2 \%$ of the total sample) showed clear evidence of scarring from ship propeller injuries and 10 whales showed "possible" injuries. Again, "possible" injuries were not used in this analysis leaving 494 whales for the analysis. These results indicate that ship strike injuries currently appear to be relatively rare on bowhead whales in Alaska (Figs. 4 and 7). Whale length appeared to explain some of the variation in frequency of whales' surviving ship propeller injuries, but the relationship was not significant $(p=0.082)$. Neither sex nor year was a significant explanatory variable. George et al. (1994) reported two whales harvested in the 1970s and 1980s

TABLE 2. Basic data on sample sizes of landed bowhead whales with scarring used in this analysis. "Total cases" is the total number of whales examined for a particular scar type (includes non-detections). "Definite" scars are those for which the authors were certain of the cause. "Possible" scars are those for which the authors could not determine the scar type with high confidence. "Cases used in analysis" excludes "possible" scars, and "\% Definite scars" is defined as (Definite /Cases used in analysis • 100).

\begin{tabular}{|c|c|c|c|c|c|}
\hline Entanglement & 514 & 59 & 29 & 485 & $12.2 \%$ \\
\hline Ship & 504 & 10 & 10 & 494 & $2.0 \%$ \\
\hline
\end{tabular}




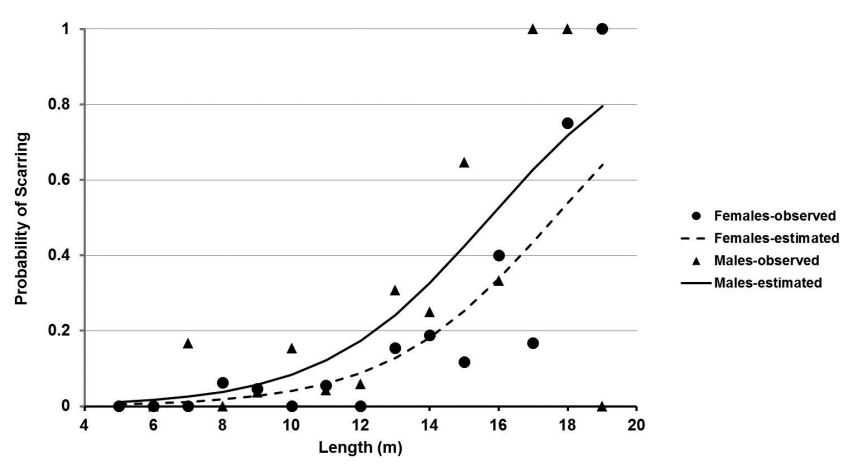

FIG. 5. Estimated probabilities of bowhead whales' exhibiting line entanglement scars as a function of length and sex. Large whales and males had significantly higher entanglement rates than subadults and females.

with propeller injuries, for an estimated scar rate of approximately $1 \%$.

\section{Killer Whales}

Of 367 usable records for killer whale scars, 29 whales (7.9\% of the total sample) had "rake marks" consistent with killer whale injuries, and another 10 had possible injuries (Figs. 3 and 8). Most injuries were localized to the fluke, and three whales had injuries to the pectoral fins.

Most bowheads more than $17 \mathrm{~m}$ long show evidence of killer whale predation attempts, particularly in the decade since 2002. Only $1 \%-2 \%$ of small bowheads $(<10 \mathrm{~m})$ showed such injuries. Year $(p=0.035)$ and body length $(p<0.001)$ explained much of the observed variation in the occurrence of scars from attempted killer whale predation. A very similar model using year-group $(p=0.044)$ and body length $(p<0.001)$ also explained much of the observed variation in the occurrence of scars from attempted killer whale predation (Fig. 8). We found a significantly higher probability of killer whale rake mark scars for bowheads in $2002-12$ than in the previous period (1990-2001).

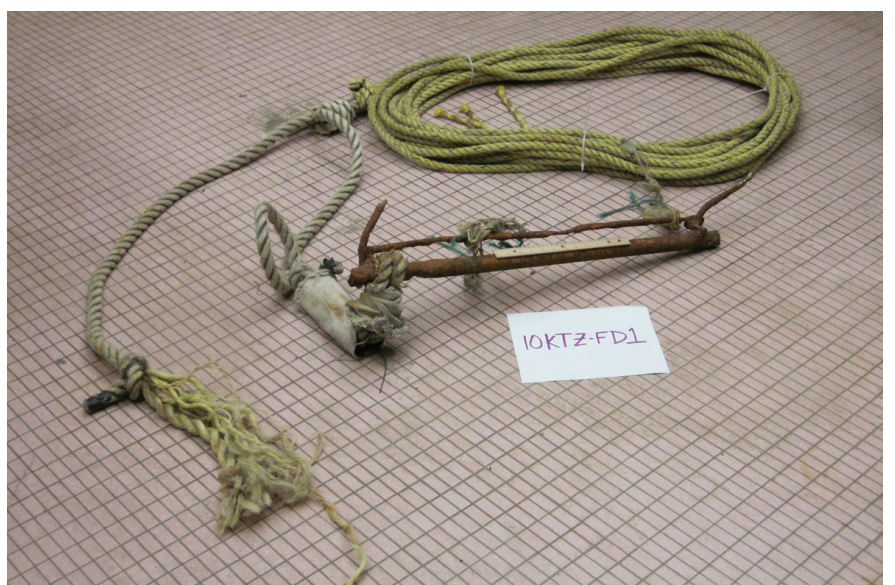

FIG. 6. Commercial pot gear removed from an entangled dead adult female bowhead whale found floating in the Chukchi Sea during 2010. Photo credit: G. Sheffield.

\section{Whales with Gear Attached}

Of the 15 reports of bowhead whales actively entangled with man-made line, commercial fishing gear, or both, seven $(47 \%)$ were found dead-stranded, while eight $(53 \%)$ were observed alive and free-swimming (Table 3, Fig. 9). Commercial pot gear was confirmed in four of the entanglement events.

\section{DISCUSSION}

Samples sizes varied for each scar type because not all whales could be fully examined for all scar types. For example, if during the processing, the flukes were cut off before the whale was hauled ashore, we could not make a full assessment of injuries from killer whales, since they typically occur on the flukes. Similarly, for line entanglement examinations it was essential that the peduncle be available for examination as that is where

TABLE 3. Opportunistic data on harvested, dead-stranded, and live bowhead whales entangled in line or gear (or both) during the period 1983-2015. Also included are notes on gear type and other observations.

\begin{tabular}{|c|c|c|c|c|}
\hline Location & Year & Id \# & Type & Comments \\
\hline Kaktovik & 1983 & - & live, swimming & Whale seen with a line attached (Reeves et al., 1983) \\
\hline Wales & 1987 & - & dead-stranded & Two lines attached to flukes (Philo et al., 1993) \\
\hline Gambell & 1989 & - & dead-stranded & Rope wrapped around head and in mouth (Philo et al., 1992) \\
\hline Barrow & 1990 & $90 \mathrm{~B} 6$ & harvested & Two ropes: one exiting mouth and one recovered in water (Philo et al., 1992) \\
\hline Barrow & 1993 & - & dead-stranded & Commercial pot line wrapped around flukes (NSB-DWM, unpubl. data) \\
\hline Chukchi Sea & 1994 & $94001 / 94002$ & live, swimming & Swimming with line attached (NMML aerial survey, 20 May 1994) \\
\hline Nuiqsut & $1990 \mathrm{~s}$ & - & harvested & Harvest report of a bowhead whale landed with rope in mouth, (NSB-DWM, unpubl. data) \\
\hline Red Dog Mine & 1998 & - & dead-stranded & "Line on whale" (National Marine Fisheries Service, unpubl. data). \\
\hline Barrow & 1999 & 99B14 & harvested & Commercial pot line entangled in mouth, flipper and tail (NSB-DWM, unpubl. data) \\
\hline Barrow & 2001 & - & live, swimming & Whale entangled with a thick green line trailing from the flukes (G. Brower, pers. comm. 2006) \\
\hline Cinder River & 2003 & - & dead-stranded & $\begin{array}{l}\text { Several lines (approx. } 3 / 4^{\prime \prime} \text { diameter) of different colors wrapped at the flukes } \\
\text { (NSB-DWM, unpubl. data) }\end{array}$ \\
\hline Point Barrow & 2003 & 033410 & live, swimming & Aerial photo of whale with a thick line attached to flukes (NOAA, unpubl. data) (Fig. 9). \\
\hline Chukchi Sea & 2010 & 10KTZ-FD1 & dead-stranded & Commercial pot gear recovered from mouth and peduncle (Sheffield, 2010) \\
\hline Point Barrow & 2011 & 01161591 & live, swimming & Aerial photo of whale with a thick yellow line attached to flukes. (NOAA, unpubl. data) \\
\hline Bering Sea & 2015 & 2015-FD2 & dead-stranded & $\begin{array}{l}\text { Found floating with a commercial pot line, two vinyl floats, and a Limited Entry Pot Permit tag } \\
\text { wrapped around the peduncle, (Sheffield and SWCA, 2015) }\end{array}$ \\
\hline
\end{tabular}




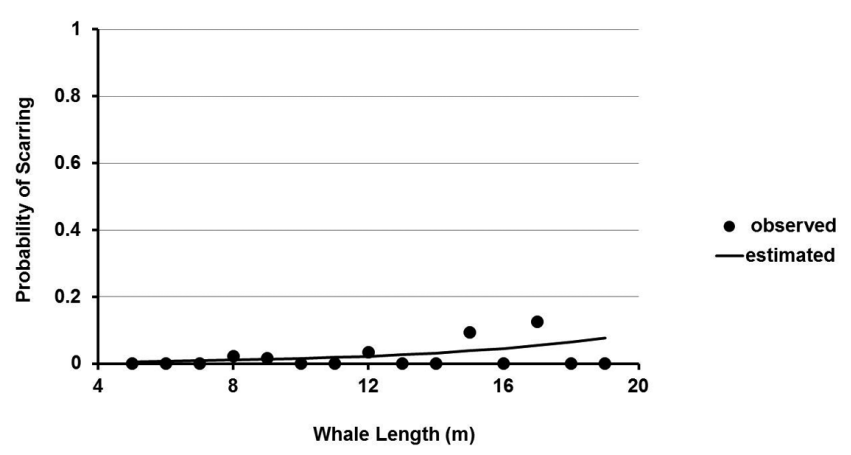

FIG. 7. Estimated probabilities of bowhead whales exhibiting ship injury scars as a function of length. There was no statistically significant trend for whale length for ship strike injuries; however, samples sizes were low.

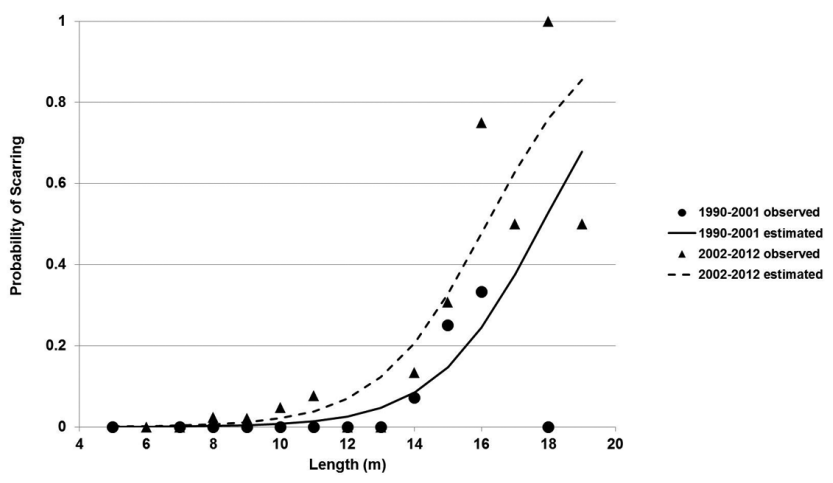

FIG. 8. Estimated probabilities of bowhead whales with killer whale-inflicted injuries as a function of whale length and decade. We found a significantly higher probability of killer whale rake mark scars for bowheads in 2002-12 than in the previous period (1990-2001).

most entanglement injuries are observed. Ship-strike injuries may have been slightly underreported because the side of the landed whale lying on the substrate is often not examined. As noted earlier, we analyzed only cases of landed whales with "definite" scar types and excluded "possible" scars. Obviously, this study estimates only the frequency of whales that survive killer whale, line entanglement, and ship collisions and does not estimate mortality rates.

Whale length appeared to explain some of the variation in prevalence of scars for all three injury types. While the bowhead age-at-length relationship is complicated by variable growth patterns and extreme longevity, length is a reasonable surrogate for age in this type of analysis (George et al., 1999; Rosa et al., 2013). Length also serves as a surrogate for time of exposure to environmental hazards, which may result in detectable injuries. Future comparisons of injury rates, either between populations or over time, should incorporate length or a similar surrogate for time of exposure to hazards as an explanatory variable to reduce potential biases in interpretation of differences or change.

The exclusion from the analyses of whales scored as "possible" may have resulted in biases in the results reported here, but we think they are minor. For instance, if $50 \%$ of the "possible" entanglement scars were true,

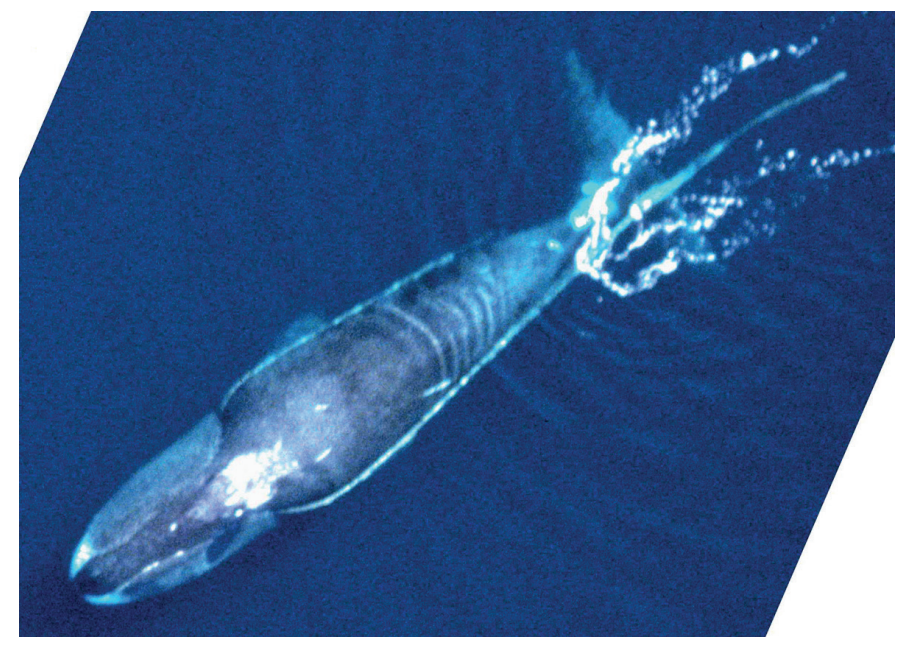

FIG. 9. Aerial photograph of a bowhead whale trailing a heavy line anchored through the mouth. The whale was photographed near Barrow, Alaska in 2003 during an aerial photo-ID survey (Koski et al., 2010). Photo Bill Koski, NMFS Scientific Research Permit.

the entanglement rate would increase from $12 \%$ to $14 \%$. Designating scars on an individual whale as "possible" for an injury type provided incentive for us to review the records and photographs for that whale carefully to see if we could make a determination of scar or no-scar according to the criteria described in the methods above. Following careful review, some scars remained classified as "possible." However, assigning a classification of scarred or not scarred to these observations would have been arbitrary and, in our view, was not justifiable in this analysis.

\section{Line Entanglement}

We suspect these entanglement scars are largely the result of interactions with commercial fishing or crabbing gear from the transboundary Bering Sea fisheries (Fig. 6). Some of the gear may be "ghost gear" abandoned because of storms and sea ice. The entanglement scars described on landed whales are unlikely to be caused by harpoon lines related to the subsistence harvest because (1) whales struck with a harpoon should have a penetrating injury or significant scar on the posterior portion of the back or retain the harpoon itself, and (2) the harpoon line, typically 0.5 inch $(1.5 \mathrm{~cm})$ in diameter with an inflatable float attached, likely does not have sufficient weight, compared to a $400 \mathrm{~kg}$ commercial crab pot, to cause the deep scarring associated with the observed entanglement injuries. We did not notice healed harpoon injuries on examined whales except on harvested whale 92B2, which had an indentation in the back with a stone harpoon end-blade embedded in it (George et al., 1995, 1999). Traditional knowledge holders from Saint Lawrence Island have observed harpooned bowhead whales using their fluke notch somewhat like a "hand in a mitten" to "pinch" the harpoon line in an attempt to remove it (C. Noongwook and P. Pungowiyi, pers. comm. 2010), which may explain scarring in the fluke notch. 
Citta et al. (2013) found spatial but not temporal overlap between active U.S, blue king crab fisheries in the central Bering Sea and satellite telemetry data of tagged bowheads. A recent entanglement event, however, suggests there is some potential for temporal overlap with the winter $\mathrm{crab}$ fishery in the U.S. Bering Sea (Sheffield and Savoonga Whaling Captains Association, 2015). Reliable data on the northern extent and timing of the Russian commercial crab fleet are difficult to locate and are not included here. In order to better understand potential temporal and spatial overlap with bowhead whale winter movements, we recommend transboundary communications with Russian fisheries managers regarding the northern extent of commercial fishing grounds.

While entanglement was highly correlated with length and sex, we suggest $\sim 12 \%$ as an overall estimate of entanglement scars in the BCB bowhead population. By contrast, Knowlton et al. (2012) estimated a much higher incidence of $82.9 \%$ for North Atlantic right whales photographically assessed for evidence of entanglement events. Neilson et al. (2009) found a very high incidence $(\sim 71 \%)$ of entanglement injuries from fishing gear for humpback whales in Southeast Alaska (SEAK). While their analytical approach differed from ours, using photographs of living whales and including "possible" scars, their minimum estimate $(52 \%)$ far exceeds the overall estimate for bowheads. This suggests that both North Atlantic right whales and SEAK humpbacks are non-lethally entangled in fishing gear much more often than bowheads, which makes sense given that their home range is within areas of high fishing effort.

Male bowhead whales had significantly higher rates of line entanglement scars than females. The higher scar rate may be due to their greater longevity and thus prolonged exposure to entanglement risk and to the fact that larger whales may be stronger than small whales and better able to survive a line entanglement (George et al., 1999; Rosa et al., 2013). Knowlton et al. (2012), in their study of North Atlantic right whales, reported that males and females became entangled at similar rates.

\section{Ship Strikes}

The fact that few bowheads (2\%) show scars from ship strikes may be explained by some combination of (1) relatively low levels of commercial ship traffic in the Pacific Arctic, (2) higher mortality resulting from ship strike injuries, and (3) other unknown factors. However, as industrial maritime ship traffic continues to increase in the Arctic, we should expect to see an increase in scars associated with ship strikes or carcasses with ship strike injuries on beaches across northern and western Alaska (Reeves et al., 2012). Model results in Table 1 indicate some relationship between scar rates and body length, but there were too few cases to allow a meaningful analysis. The scars we scored as ship strikes appeared to be caused by propeller wounds. It is possible that we missed injuries from blunt trauma associated with ship collisions, since non-penetrating wounds should not necessarily result in a visible superficial scar. Such an injury may be associated with subcutaneous scar tissue arising from a hematoma or other tissue damage, but it would be difficult to assign cause to such injuries.

\section{Killer Whale}

We suspect that killer whale scars are more common on large whales simply because older whales have more exposure time to predation attempts. Also, younger bowhead whales may more often be killed during an attack by killer whales. This hypothesis is consistent with speculation in Reinhart et al. (2013) that younger Eastern Canada-West Greenland (ECWG) bowheads are more likely to be killed during an attack and larger, older bowhead whales have greater exposure time to killer whales. These authors also found rake marks on a large number of adult females, which they may have acquired trying to protect their calves from killer whales. Reinhart et al. (2013) also provide a good review of killer whale scar rates for other bowhead populations and whale species and discuss problems associated with estimating reliable scar rates. For instance, scar rates for various Pacific Ocean humpback populations range widely, from $0 \%$ to more than $40 \%$.

The increase in killer whale scarring that we report is intriguing and consistent with results reported in Reinhart et al. (2013) for Eastern Canadian Arctic bowheads. Their data indicate a dramatic increase in rake marks on ECWG bowheads from 1986 to 2012 . Killer whale marks were found on an estimated $10.2 \%$ of that population (Reinhart et al., 2013). The reasons for this increase might include better reporting or sampling bias (or both), an increase in killer whale population size, an increase in occurrence of killer whales at high latitudes (Clarke et al., 2013), and a longer open water period offering more opportunities to attack bowheads.

George et al. (1994) also noted a "considerably higher" frequency of killer whale scars on bowheads more than $13 \mathrm{~m}$ in length (presumably adults). They reported the scar frequency for "definite" killer whale bites in 1976-92 ranged from $4.1 \%$ to $6.1 \%$ (George et al., 1994). The current study (1990-2012) overlaps slightly with this earlier work (1990-92). However, the injury rate reported in George et al. (1994) is lower than the current rate of $\sim 8 \%$, which suggests that killer whale injuries have increased since that period.

\section{SUMMARY}

While BCB bowheads inhabit relatively remote Arctic seas, they are subject to anthropogenic injuries associated with ship strikes $(\sim 2 \%)$ and line entanglement $(\sim 12 \%)$ similar to those found in other large cetacean populations, but generally at a lower frequency. Current evidence 
suggests that most $\mathrm{BCB}$ bowhead entanglement injuries are inflicted by Bering Sea crab or cod fisheries, and these include injuries from gear that may have been lost or abandoned. Entanglement rates are higher for very large bowheads $(>17 \mathrm{~m})$ than for subadults. We suspect this is because they have had far greater exposure time ( $>50$ years) to entanglement hazards than smaller whales or are large enough to survive the insult. Scars associated with vessel strikes are infrequent; however, with increased industrial vessel traffic in the Arctic, one might expect ship strikes to increase. Scarring from attempted killer whale predation was evident on $\sim 8 \%$ of landed whales, which is slightly lower than the percentage in the ECWG bowhead population and some other large cetacean populations. Killer whale scarring was statistically more frequent in the second half of the study (2002-12).

Whales that die from entanglement in the Bering Sea crab or pot gear may go undetected in many cases. Likewise, most bowheads killed by either killer whales or ship collisions probably go unrecorded as well. Obviously, the frequency of injuries reported here reflects only the whales that survived these incidents.

Considering that bowhead habitat is changing rapidly (e.g., sea ice reduction), industrial ship traffic in the Arctic is increasing, and commercial fishing operations are expanding northward, we strongly recommend continued monitoring of scarring and injuries on harvested bowheads into the future as a means of documenting change.

\section{ACKNOWLEDGEMENTS}

We thank all the whaling communities, and specifically Kaktovik, Barrow, Gambell, Point Hope, Savoonga, and Wainwright, for allowing us to examine their bowhead whales. This project is the result of hard work by many people involved in examining harvested and stranded whales over many years. This study would not have been possible without the help and guidance of (alphabetically): the Alaska Eskimo Whaling Commission, Tom Albert, Leandra de Sousa, Cyd Hanns, Jason Herreman, Merlin Koonooka, Joe Kaleak, George Noongwook, Todd O'Hara, Mike Philo, Leslie Pierce, Dave Ramey, Geof Givens, Cheryl Rosa, NOAA - Alaska Marine Mammal Stranding Network, and many others. This project was conducted under National Marine Fisheries Service Permits: \#782-1694, \#9321489, \#1009, \#814-1899, and \#17350. Funding was provided by the North Slope Borough Department of Wildlife Management and the Collaborative Arctic Alaska Studies Program (CAASP), formerly the NSB-Shell Baseline Studies Program. We thank Michael Macrander for his support of the CAASP program.

\section{REFERENCES}

Brandon, J.R., and Wade, P.R. 2006. Assessment of the BeringChukchi-Beaufort Seas stock of bowhead whales using Bayesian model averaging. Journal of Cetacean Research and Management 8(3):225-239.
Burnham, K.P., and Anderson, D.R. 2001. Kullback-Leibler information as a basis for strong inference in ecological studies. Wildlife Research 28(2):111-119.

https://doi.org/10.1071/WR99107

. 2002. Model selection and multimodel inference: A practical information-theoretic approach, 2nd ed. New York: Springer-Verlag.

Citta, J.J., Burns, J.J., Quakenbush, L.T., Vanek, V., George, J.C., Small, R.J., Heide-Jørgensen, M.P., and Brower, H. 2013. Potential for bowhead whale entanglement in cod and crab pot gear in the Bering Sea. Marine Mammal Science 30(2):445-459.

https://doi.org/10.1111/mms.12047

Clarke, J.T., Christman, C.L., Brower, A.A., and Ferguson, M.C. 2013. Distribution and relative abundance of marine mammals in the northeastern Chukchi and western Beaufort Seas. 2012. Annual Report, OCS Study BOEM 2013-00117. Seattle, Washington: National Marine Mammal Laboratory, Alaska Fisheries Science Center. http://www.afsc.noaa.gov/nmml/pdf/comida-2012-report.pdf

Crawley, M.J. 2007. The R book. West Sussex, England: John Wiley \& Sons, Ltd. https://doi.org/10.1002/9780470515075

DeMarban, A. 2015. Barrow whalers haul in bonus bowhead killed by unknown causes. Alaska Dispatch News, October 8.

George, J.C., and Suydam, R. 1998. Observations of killer whale (Orcinus orca) predation in the northeastern Chukchi and western Beaufort Seas. Marine Mammal Science 14(2):330-332. https://doi.org/10.1111/j.1748-7692.1998.tb00722.x

George, J.C., Philo, L.M., Hazard, K., Withrow, D., Carroll, G.M., and Suydam, R. 1994. Frequency of killer whale (Orcinus orca) attacks and ship collisions based on scarring on bowhead whales (Balaena mysticetus) of the Bering-Chukchi-Beaufort Seas stock. Arctic 47(3):247-255. https://doi.org/10.14430/arctic1295

George, J.C., Suydam, R.S., Philo, L.M., Albert, T.F., Zeh, J.E., and Carroll, G.M. 1995. Report of the spring 1993 census of bowhead whales, Balaena mysticetus, off Point Barrow, Alaska, with observations on the 1993 subsistence hunt of bowhead whales by Alaska Eskimos. Report of the International Whaling Commission 45:371-386.

George, J.C., Bada, J., Zeh, J., Scott, L., Brown, S.E., O'Hara, T., and Suydam, R. 1999. Age and growth estimates of bowhead whales (Balaena mysticetus) via aspartic acid racemization. Canadian Journal of Zoology 77(4):571-580. https://doi.org/10.1139/z99-015

Givens, G.H., Edmondson, S.L., George, J.C., Suydam, R., Charif, R.A., Rahaman, A., Hawthorne, D.L., Tudor, B., Delong, R.A., and Clark, C.W. 2016. Horvitz-Thompson whale abundance estimation adjusting for uncertain recapture, temporal availability variation, and intermittent effort. Environmetrics 27(3):134-146. https://doi.org/10.1002/env.2379

Hosmer, D.W., and Lemeshow, S. 2000. Applied logistic regression, $2^{\text {nd }}$ ed. New York: John Wiley \& Sons, Inc. https://doi.org/10.1002/0471722146 
Knowlton, A.R., Hamilton, P.K., Marx, M.K., Pettis, H.M., and Kraus, S.D. 2012. Monitoring North Atlantic right whale Eubalaena glacialis entanglement rates: A 30 yr retrospective. Marine Ecology Progress Series 466:293-302. https://doi.org/10.3354/meps09923

Koski, W.R., Zeh, J.E., Mocklin, J.A., Davis, A.R., Rugh, D.J., George, J.C., and Suydam, R. 2010. Abundance of BeringChukchi-Beaufort bowhead whales (Balaena mysticetus) in 2004 estimated from photo-identification data. Journal of Cetacean Research and Management 11(2):89-99.

Moore, M.J. 2014. How we all kill whales. ICES Journal of Marine Science 71(4):760-763. https://doi.org/10.1093/icesjms/fsu008

Moore, M.J., Knowlton, A.R., Kraus, S.D., McLellan, W.A., and Bonde, R.K. 2004. Morphometry, gross morphology and available histopathology in North Atlantic right whale (Eubalaena glacialis) mortalities (1970-2002). Journal of Cetacean Research and Management 6(3):199-214.

Moore, S.E., and Reeves, R.R. 1993. Distribution and movement. In: Burns, J.J., Montague, J.J., and Cowles, C.J., eds. The bowhead whale. Society for Marine Mammalogy, Special Publication No. 2. Lawrence, Kansas: Allen Press. 313-386.

Neilson, J.L., Straley, J.M., Gabriele, C.M., and Hills, S. 2009. Non-lethal entanglement of humpback whales (Megaptera novaeangliae) in fishing gear in northern Southeast Alaska. Journal of Biogeography 36(3):452-464.

https://doi.org/10.1111/j.1365-2699.2007.01820.x

Philo, L.M., George, J.C., and Albert, T.F. 1992. Rope entanglement of bowhead whales (Balaena mysticetus). Marine Mammal Science 8(3):306-311. https://doi.org/10.1111/j.1748-7692.1992.tb00414.x

Philo, L.M., Shotts, E.B., Jr, .and George, J.C. 1993. Morbidity and mortality. In: Burns, J.J., Montague, J.J., and Cowles, C.J., eds. The bowhead whale. Society for Marine Mammalogy, Special Publication No. 2. Lawrence, Kansas: Allen Press. 275-312.

Quakenbush, L.T., Citta, J.J., George, J.C., Small, R.J., and HeideJørgensen, M.P. 2010. Fall and winter movements of bowhead whales (Balaena mysticetus) in the Chukchi Sea and within a potential petroleum development area. Arctic 63(3):289-307. https://doi.org/10.14430/arctic1493

Quakenbush, L., Citta, J., George, J.C., Heide-Jørgensen, M.P., Small, R., Brower, H., Harwood, L., et al. 2012. Seasonal movements of the Bering-Chukchi-Beaufort Stock of bowhead whales: 2006-2011 satellite telemetry results. Paper SC/64/ BRG1 presented to the International Whaling Commission Scientific Committee.

R Development Core Team. 2009. R: A language and environment for statistical computing. Vienna, Austria: R Foundation for Statistical Computing. http://www.R-project.org
Read, A.J., Drinker, P., and Northridge, S. 2006. Bycatch of marine mammals in U.S. and global fisheries. Conservation Biology 20(1):163 - 169 . https://doi.org/10.1111/j.1523-1739.2006.00338.x

Reeves, R., Mitchell, E., Mansfield, A., and McLaughlin, M. 1983. Distribution and migration of the bowhead whale, Balaena mysticetus, in the eastern North American Arctic. Arctic 36(1):5-64.

https://doi.org/10.14430/arctic2243

Reeves, R., Rosa, C., George, J.C., Sheffield, G., and Moore, M. 2012. Implications of Arctic industrial growth and strategies to mitigate future vessel and fishing gear impacts on bowhead whales. Marine Policy 36(2):454-462.

https://doi.org/10.1016/j.marpol.2011.08.005

Reinhart, N.R., Ferguson, S.H., Koski, W.R., Higdon, J.W., LeBlanc, B., Tervo, O., and Jepson, P.D. 2013. Occurrence of killer whale Orcinus orca rake marks on Eastern Canada-West Greenland bowhead whales Balaena mysticetus. Polar Biology 36(8):1133-1146. https://doi.org/10.1007/s00300-013-1335-3

Rosa, C., Zeh, J., George, J.C., Botta, O., Zauscher, M., Bada, J., and O'Hara, T.M. 2013. Age estimates based on aspartic acid racemization for bowhead whales (Balaena mysticetus) harvested in 1998-2000 and the relationship between racemization rate and body temperature. Marine Mammal Science 29(3):424-445. https://doi.org/10.1111/j.1748-7692.2012.00593.x

Rugh, D.J., Braham, H.W., and Miller, G.W. 1992. Methods for photographic identification of bowhead whales, Balaena mysticetus. Canadian Journal of Zoology 70(3):617-624. https://doi.org/10.1139/z92-090

Sheffield, G. 2010. A bowhead whale entangled in Bering Sea commercial pot gear, Chukchi Sea. Alaska Dept. of Fish and Game - Nome, Report to the North Slope Borough Department of Wildlife Management, PO Box 69, Barrow, Alaska 99723.

Sheffield, G., and SWCA (Savoonga Whaling Captains Association). 2015. Bowhead whale entangled in commercial crab pot gear recovered near Saint Lawrence Island, Bering Strait. University of Alaska Fairbanks, Alaska Sea Grant, Marine Advisory Program (Nome), Report to the North Slope Borough Department of Wildlife Management, PO Box 69, Barrow, Alaska 99723.

Suydam, R., George, J.C., Person, B., Ramey, D., Stimmelmayr, R., Sformo, T., Pierce, L., and Sheffield, G. 2016. Subsistence harvest of bowhead whales (Balaena mysticetus) by Alaskan Eskimos during 2015 and other aspects of bowhead biology and science. Paper SC/66b/BRG01 presented to the International Whaling Commission Scientific Committee, Bleb, Slovenia.

Vate Brattstrom, L., Mocklin, J., Tudor, B., George, J.C., and Givens, G.H. 2016. Update on the bowhead whale aerial photoID program and 2011 aerial spring survey. Paper SC/66B/ BRG04 presented to the International Whaling Commission Scientific Committee. 